\title{
Building Bridges, Changing Lives: Eco-Justice and Teacher Education
}

\author{
Shylaja $\mathrm{C} \mathrm{V}^{*}$
}

\section{Abstract}

Eco-justice pedagogy is an approach that addresses the necessity of sensitizing the students about the nature of the cultural and ecological changes occurring now on a worldwide scale. It includes a critical inquiry that helps students recognize and participate in the noncommodified aspects of community life. This paper emphasizes upon giving special attention to what teachers need to understand about how the language of the curriculum is based on root metaphors that organize thinking in ways that ignore environmental racism and the marginalization of different cultural approaches to community, not oriented toward dependency upon modern technology and consumerism.

Keywords: Eco-justice, eco-justice pedagogy, root metaphors, teacher education, global citizenship etc.

\section{Introduction}

Albert Schweitzer famously observed "Man has lost the capacity to foresee and forestall, he will find his end by destroying the earth."

\footnotetext{
* Oriental College of Teacher Education, Kozhikode, India; shylajacv.scv@gmail.com
} 
United Nations has declared the decade 2014-2024 as the decade of "Sustainable Energy for All". Education for Sustainable Development (ESD), Eco-literacy, Eco-pedagogy, Eco-justice, Ecojustice Education etc. has emerged in the $21^{\text {st }}$ Century as new academic areas of interest. It probes interactions between global, social, and human systems.

\section{Current Scenario}

Excessive consumption of fossil fuels, massive destruction of forests and eco-systems, over exploitation of natural resources and indiscriminate release of hazardous pollutants into the environment are depleting the available natural resources, as our present generation is on its way to consume them completely. There are certain questions that humanity should ask itself:

1. Are we plundering nature, which has to be handed over to posterity?

2. Aren't we looting the resources of the future community and depriving them of their right to a fine life?

We cut down forests for our present needs of firewood, or burn petroleum products for our luxuries of the present day, not bothering that these resources are exhaustible. The damage that we cause to the environment in this process can make it difficult for the future generation to live on earth comfortably. Our development should be based on the principles of sustainability and sustainable development, so that a better quality of life is assumed for everyone now and for the future generations to come.

Human sustainability on Earth implies responsible and proactive decision making and innovation that minimizes negative impact and maintains a balance between social, environmental and economic growth to ensure the survival of all species now and in the future. It requires the reconciliation of environmental, social equity and economic demands- also referred to as the three pillars of sustainability. Healthy eco-systems and environments are necessary for the survival and flourishing of human beings and other organisms. Effective management of environment is essential for reducing negative human impact on natural environment. This 
can be based largely on information gained from earth science, environmental science and conservation biology.

Environmental protection is influenced by three interwoven factors: environmental legislation, ethics and education. Each of these factors plays its part in influencing international and national level environmental decisions and personal level environmental values and behaviours. The world calls for a deeper understanding of the ways of nature and development path of science and technology in consonance with the ways of nature.

Education can never merely be for the sake of individual enhancement. Education pulls us into the common world or it fails altogether. Education enables us to understand ourselves and others and our links with the wider natural and social environment, and this understanding serves as a durable basis for building respect. Along with a sense of justice, responsibility, exploration and dialogue, ESD and Eco-justice education aims to move us to adopt behaviours and practices, which will enable us to live a full life without being deprived of the basics. Basic values such as respect for life, protection of the environment, social justice and democracy should be transacted through the curriculum.

\section{Major Objectives of the Study}

1. To gauge and spread awareness on eco-justice and ecojustice education

2. To assess and emphasize the importance of eco-justice in the current scenario.

3. To appreciate and elaborate the role of teachers and teacher educators in eco-justice.

Eco-justice is an approach that analyses the deep cultural roots of intersecting social and ecological crises, focusing especially on the globalizing cultural, economic and political forces of Western consumer culture. Eco-justice scholars and educators believe that various cultures support and teach about the ways that actively resist the colonizing forces by protecting and revitalizing their commons-i.e., the social practices and traditions, languages and relationships with the land necessary to the healthy regeneration of other communities. Eco-justice educators and activists understand 
social justice to be inseparable from, and even embedded, in questions regarding ecological wellbeing.

We understand the commons as social and political, cultural and ecological, ontological and epistemological including often ancient practices, relationships, traditions, knowledge, skills and ways of being-both human and more than human. We especially acknowledge our engagement with complex and diverse ecological communities. We encourage a wide range of critical / ethical perspectives from within artistic, scholarly, activist and other community groups. These could include presentations, performances or exhibitions that express and examine the interactions and interdependencies among diverse cultures, languages and living systems.

To define eco-justice, "it is the fair treatment and meaningful involvement of all people regardless of race, colour, national origin or income with respect to the development, implementation and enforcement of environmental laws, regulations and policies".

Eco-justice emerged as a concept in the US in the early 1970s. The term has two distinct uses. The first and more common usage describes a social movement whose focus is on the fair distribution of environmental benefits and burdens. Second, it is an interdisciplinary body of social science and literature that includes theories of the environment, theories of justice, environmental law and governance, environmental policy and planning, development, sustainability and political ecology.

\section{Origin of Eco-justice}

After the first Earth Day, in April 22, 1970, "eco-justice" became the theme of a group of North American ecumenically engaged Christian ethicists. In a seminal article on "Ecological Responsibility and Economic Justice", Episcopal priest Norman Faramelli of the Boston Industrial Mission emphasized that "choosing (to work for)ecology instead of (against) poverty or vice versa is to make a bad choice; the way ahead is to choose both". To foster converging commitments to ecology and justice, American Baptist leaders Richard Jones and Owen Owens introduced the term 'eco-justice'. 
By 1973, a strategy to advance integrative ethics of ecology and justice became the focus of an ecumenical campus ministry initiative at Cornell University called the Eco-justice Project and Network (EJPN), initiated and coordinated for two decades by Presbyterian social ethicist William. E. Gibson. He defined ecojustice as : " the well-being of human kind on a thriving earth...an earth productive of sufficient food, with water fit for all to drink, air fit to breathe, forests kept replenished, renewable resources, continuously renewed, non-renewable resources used as sparingly as possible so that they will be available(to the future generations) for their most important uses. On a thriving earth, providing sustainable sufficiency for all, human wellbeing is nurtured not only by the provision of these material necessities, but also by a way of living within the natural order that is fitting: respectful of the integrity of natural systems and of the worth of non-human creatures, appreciative of the beauty and mystery of the world of nature."

Ecological responsibility in linkage with social justice is what the world needs right now. Healthy earth community requires advocacy and action on urgent environmental issues in ways that connected with struggles for social and economic justice. Ecojustice envisions and values ecology and justice together, since there will be little environmental health without socio-economic justice and vice versa. Some discussions of "sustainability", a prominent concept in environmental studies and political discourse have parallel ethical meaning, to the extent that they encompass social justice principles. (Cobb- 1992).

Today, there is growing appreciation for of what is often called an eco-justice ethic that holds together, concerns for the natural world and for human life, that recognizes that devastation of the environment and economic injustice go hand in hand, and that affirms that environmental and human rights are indivisible (Pedersen,1998). The vision and values of eco-justice ethics express a spiritually grounded moral posture of respect and fairness toward all creation, human and non-human. Eco-justice ethics are shaped by religious insights and scientific knowledge, interwoven with social, economic and political experience. 


\section{Nature and importance of eco-justice education: Current scenario}

The world is facing enormous ecological and social problems - top soil loss, overfishing, and acidification of our oceans, loss of potable water and access to safe food sources, and global climate change are all just the tip of the iceberg. It seems obvious that anyone involved in the education of the future citizenry should be asking

(i) How did we get here?

(ii) Who are we within all of this?

(iii) What can we do at this point to understand and address such a challenging and complicated situation?

Teacher educators have become fairly adept at addressing social justice issues implied by these questions, focusing on the ways schools and our larger social systems reproduce racism, and socioeconomic inequalities. Curriculum and instruction, social foundations and educators are just beginning to take the ecological issues seriously. On the other hand, though environmental educators have been working on issues related to environmental degradation for years, their approach has for the most part bracketed out any relation of these problems to underlying sociocultural questions, preferring instead to introduce students to the study and management of nature primarily through the application of science and mathematics. This dualism between social justice education and environmental education is a reflection of a deeply rooted cultural problem that hyper-separates humans from the more than human world and promotes the general idea that humans have the right to manage, exploit and control both other creatures and "other" humans. (Plumwood, 2002).

\section{Principles of Eco-justice education}

There are four principles of eco-justice education.

1. Learn more about the world in which we live: the ecological state of the world; the positive actions that people, corporate and governments at all levels are taking care for the earth and what we can do to make a difference.

2. Learn more about the resources of faith: from the Bible, from our tradition, from current theological writings - that 
can inform and inspire us to see all of creation as belonging to God and then to care about it and to care for it.

3. Combine each learning experience with an action, either personal or communal; that is, follow-up on your learning with decisions and actions. Then reflect on those actions and determine where to go next.

4. Learn in a way that honours people as part of creation; respect diversity, allow people to grow and change naturally, learn in a pleasing environment.

As we begin to think about the educational implications of ecojustice, it becomes immediately clear that there are at least some eco-justice issues that can be addressed in the eco-justice curriculum of the public schools and universities. These include:

1. The need to challenge the assumptions and practices that are the cause of environmental racism.

2. The need to understand the ideological, economic and technological forces that lead to the domination of the South by the North - and to recognize how the revitalization of the commons represents an alternative to the history of Western economic colonization.

3. The need to understand the many ways in which the commons can be revitalized as well as how the technoscientific industrial forces continue the process of enclosure;

4. The need to help ensure that the prospects of future generations are not diminished by the greed and selfcentered hyper- consumerism of this generation

5. The need to act politically in ways that promote earth democracy.

An eco-justice curriculum will require a radical shift in educational priorities-and by extension, in what is studied in teacher education programmes and graduate education programmes.

\section{Role of Teachers in Eco-justice Education}

Role of teachers in disseminating knowledge among the members of future generation and bringing about changes in them is 
remarkably great and is evident. The role teachers can perform the same way, for disseminating the contents of eco-justice is equally important. The question that may arise is that how teachers can be equipped to realize this objective of eco-justice. The right answer is to produce ideal teachers, competent and committed enough to mould the future generation so as to be accustomed to cherish the vision and mission of eco-justice. For this, the only option is the revamping of teacher education curriculum to effect that the future teachers are to be trained instead of being educated. A lot of things are to be considered before entering into this venture.

Where to start; in the pre-primary level, primary, secondary or higher education level? In which areas changes should be brought about and in what dimensions? How it can be materialized? All these and many other questions are to be answered before reaching alternatives while finding solution to this noble venture.

Teachers constitute the largest population of professionals in many nations including developing as well as developed nations. Teaching is a broad classification of activities. It is the only profession, which is closely related with the whole community. There is a deep relationship between the work of teachers and the attitudes, values, beliefs, and even behaviours of the beneficiaries of the efforts made by teachers in general.

"People in this country have been slow to recognize that education is a profession for which intensive preparation is necessary as it is in any other profession". This concern is expressed in the University Education Commission Report (1948-49). The report is very much alive in its relevance today. The Education Commission (1964-66) professed, "The destiny of India is being shaped in her classrooms". So did the National Policy on Education (1986) emphasize: "The status of the teacher reflects the socio-cultural ethos of the society; it is said that no people can rise above the level of its teachers." Such exhortations are indeed, an expression of the important role played by the teachers as transmitters, inspirers and promoters of man's eternal quest for knowledge. It is obvious that the education and training of a prospective teacher will be effective to the extent that it has been delivered by teacher educators who are competent and professionally equipped for the job. The quality of pedagogical inputs in teacher education programmes and the 
manner in which they are transacted to realize their intended objectives depend largely on the professional competence of teacher educators.

In the present scenario of globalization, to cope with the effects of globalization and privatization of teacher education, the system of teacher education and teacher educator preparation has to be reoriented and re-structured. Revamping of teacher education is very essential to upgrade, enrich and maintain proper balance between quality and quantity of teacher education.

\section{Revamping teacher education and teacher educator preparation}

Revamping of teacher education may be materialized with a view that the new curriculum may have the provisions for moulding teachers, in such a way that they can mould socially responsible citizens. Intensive training may be given to student teachers so that the values they should have, become a part of themselves. As a first step of revamping, MEd curriculum may be materialized, so that they can train BEd students, who, in turn, can be role models for the future generations. After MEd curriculum, BEd curriculum and then the DEd curriculum and then the curricula for general education from pre-primary to higher education may be revised to the effect that eco-justice will become a core subject in the general education stream.

Our former President, Dr A. P. J. Abdul Kalam, in his book "India 2020: A Vision for the Millennium" highlighted that development could be said to be sustainable only if we ensured a secure and enjoyable present and better future for everyone.

\section{Global Citizenship Education and Eco Justice}

People all over the world are struggling with problems of a magnitude no other generation has faced. Even in the most affluent nations, millions of people suffer from hunger, hopelessness and unattended health problems. Global citizenship education aims to empower learners to assume active roles to face and resolve global challenges to a more peaceful, tolerant, inclusive and secure world. UNESCO's approach to GCED focuses on the following areas: 
1. Global advocacy and policy dialogue

2. The global measurement or progress on GCED and ESD

3. Peace and human rights education

4. Preventing violent extremism through education

Global citizenship for education is for all ages-children, young people and the adults alike. GCED nurtures respect for all, building a sense of belonging to a common humanity and helping learners to become responsible and active global citizens.

\section{Conclusion}

In this age of educational upheaval, educators and policy makers alike have an opportunity to dramatically change the nature of education-regardless of our discipline or position in the educational system. We can make a tremendous difference to the entire social world and the preservation of the earth for subsequent generations if we reprioritize education for global citizenship. In the words of John Dewey, "As a society becomes more enlightened, it realizes that it is responsible not only to transmit and conserve the whole of its existing achievements, but, only such as make for a better future society. The school is the chief agency for the accomplishment of this end".

\section{References}

Bowers, C.A. (2000). Let them Eat Data: How Computers Affect Education, Cultural Diversity and the Prospects of Ecological Sustainability. Athens, GA: University of Georgia Press.

Bowers, C.A. (2003). Mindful Conservation Rethinking the Ideological and Educational Basis of an Ecologically Sustainable Future. Lanham, MD: Rowman \& Littlefield.

Freire, P. (1973). Education for Critical Consciousness. New York: Seabury Press.

Giroux, H. A. (1988). Teachers as intellectuals: Toward a critical pedagogy of learning. Greenwood Publishing Group.

Illich, I. (1978). Toward a History of Needs. New York: Pantheon Books.

Roberts, P. (2000). Education, Literacy and Humanization: Exploring the Work of Paulo Freire. Westport, CN: Bergin \& Garve. 